KS. LUCJAN ŚWITO

Wydział Teologii

Uniwersytetu Warmińsko-Mazurskiego w Olsztynie

\title{
PRAWO KANONICZNE W FORMACJI DO KAPŁAŃSTWA. MIĘDZY „TRADYCJĄ FORMACYJNĄ" A WYZWANIAMI WSPÓŁCZESNOŚCI W ŚWIETLE „RATIO FUNDAMENTALIS INSTITUTIONIS SACERDOTALIS” Z 6 GRUDNIA 2016 ROKU
}

Treść: Wstęp. - 1. Kontekst jurydyczny. - 2. Kontekst prawnomajątkowy. - 3. Kontekst prawnorodzinny i społeczny. - Zakończenie.

\section{Wstęp}

Troska o formację kandydatów do kapłaństwa od wieków ${ }^{1}$ należała do istotnych zadań biskupa i całej wspólnoty Kościoła partykularnego. Formacja ta nigdy nie polegała jedynie na przekazie określonego zasobu wiedzy, była i jest materią daleko bardziej złożoną i można mówić o niej w wielu różnorodnych aspektach i wymiarach. To przede wszystkim wychowanie, czyli wywołanie w osobowości odbierającego tę wiedzę zamierzonych zmian, przepojenia go ideą, którą winien

\footnotetext{
${ }^{1}$ Początki seminarium sięgają II w. po Chrystusie, kiedy domostwa biskupów stanowiły pierwsze środowiska przysposabiania przyszłych kapłanow. W tym samym wieku powstały szkoły katechetyczne w Cezarei Palestyńskiej, Antiochiii, Aleksandrii i Rzymie. Poźniej powołano specjalny urząd archidiakona dla wychowywania nowych duchownych. Przygotowaniu kapłanów służyły specjalne kolegia ustanawiane przy uniwersytetach. Sobor Trydencki postanowił, aby seminaria duchowne były prowadzone w całym Kościele (K. Pawlina, Kandydaci do kapłaństwa trzeciego tysiąclecia, Warszawa 2002, s. 17-18).
} 
uznać za własną i nią żyć i działać pod jej wpływem. Na określenie tego wychowania prawodawca kościelny używa wyrażenia formatio i institutio. Termin formatio został użyty dla określenia formacji duchowej $^{2}$ oraz formacji ogólnej czyli humanistycznej, jaką alumni mają wynieść z seminarium duchownego ${ }^{3}$, natomiast na wyrażenie kształcenia naukowego i formowania duszpasterskiego alumnów użyto w Kodeksie Prawa Kanonicznego z 1983 r. wyrażenia institutio ${ }^{4}$.

Zatrzymując się na aspekcie normatywnym tytułem uwag wprowadzających odnotować należy, iż formacja do kapłaństwa została skodyfikowana w prawodawstwie kościelnym według norm hierarchicznie uporządkowanych. Należy do nich ustawodawstwo powszechne oraz partykularne, ustanowione przez konferencje biskupów i biskupów diecezjalnych, dostosowane do miejscowych potrzeb. Ustawodawstwo powszechne obejmuje zarówno normy zawarte w Kodeksie Prawa Kanonicznego z 1983 r., przede wszystkim te dotyczące seminariów duchownych, które odpowiadają wskazaniom zawartym w dekrecie Soboru Watykańskiego II o formacji kapłańskiej „Optatam totius", jak i w "Ratio fundamentalis institutionis sacerdotalis”. Mają one charakter norm ramowych dla całego Kościoła. Z kolei ustawodawstwo partykularne, uchwalone zgodnie ze wskazaniami kan. 242-243 KPK, obejmuje krajowy program formacji kapłańskiej (tzw. „Ratio” krajowe) opracowany przez Konferencje Episkopatów z uwzględnieniem potrzeb poszczególnych krajów lub prowincji kościelnych. Określa on strukturę seminariów, dyscyplinę oraz program

${ }^{2}$ Kan. $235 \$ 1$, kan. 244, kan. $245 \$ 1$ KPK.

${ }^{3}$ Kan. 251, kan. 255, kan. $259 \$ 2$ KPK.

${ }^{4}$ Kan. 244, kan. 248, kan. 255 KPK. Zob. też P. Wierzbicki, Znaczenie okresu propedeutycznego w formacji kandydatów do kapłaństwa, Kościół i Prawo 2015, nr 2, s. 101-117.

${ }^{5}$ Dekret o formacji kapłańskiej Optatam totius, w: Sobór Watykański II. Konstytucje, dekrety, deklaracje. Tekst polski, Poznań 1986, s. 286-300.

${ }^{6}$ Dokument Kongregacji Edukacji Nauki z 6 stycznia 1970 r., aktualizowany przez nią 19 marca 1985 r. i znowelizowany przez Kongregację ds. Duchowieństwa 8 grudnia $2016 \mathrm{r}$. 
studiów seminaryjnych i powinien być zatwierdzony przez Stolicę Apostolską ${ }^{7}$.

Dokument Kongregacji Edukacji Katolickiej pt. „Ratio fundamentalis institutionis sacerdotalis" promulgowany 6 stycznia $1970 \mathrm{r}$. i aktualizowany przez nią 19 marca 1985 r., doczekał się kolejnej nowelizacji. W okresie bowiem ponad 30 lat obowiązywania norm wymienionego dokumentu, znaczącym zmianom uległy konteksty

${ }^{7}$ Zob. kan. $242 \$ 1$ KPK. Ustawodawstwo partykularne obejmuje również własny regulamin każdego seminarium zatwierdzony przez biskupa diecezjalnego (w przypadku seminarium diecezjalnego) lub przez wszystkich biskupów zainteresowanych (w przypadku seminarium międzydiecezjalnego). Stanowi on dalsze dostosowanie programu zawartego w krajowym „Ratio” do miejscowych warunków, a zwłaszcza doprecyzowanie tych punktów dyscypliny, „które dotyczą codziennego życia alumnów oraz porządku całego seminarium” (kan. 243 KPK). Prawodawca, zostawiając swobodę biskupowi diecezjalnemu w uszczegóławianiu zasad życia seminaryjnego wskazuje ogólne zasady, jakimi biskup powinien się kierować i czego nie może pominąć w kształtowaniu duchowieństwa. Norma kan. 244 KPK stanowi, iż „Duchowa formacja alumnów w seminarium oraz kształcenie doktrynalne winny być harmonijnie ułożone i tak ukierunkowane, aby alumni, każdy zgodnie z własną zdolnością, zdobywali wraz z odpowiednią ludzką dojrzałością ducha Ewangelii i ścisłą łączność z Chrystusem”. Pokazuje, że tylko właściwie przygotowana i spójna formacja, obejmująca całość zagadnień duchowych, doktrynalnych oraz duszpasterskich, przekazywana we właściwy sposób, może pomóc w kształtowaniu postawy kapłańskiej na wzór Chrystusa. Z prawnego punktu widzenia kan. 244-258 KPK stanowią zrąb zasadniczych norm, a niekiedy także warunków koniecznych, które powinno uzupełnić i rozwinąć prawodawstwo partykularne. Równocześnie interpretacja tych zasad wymaga odniesienia do szerokiego kontekstu nauczania Kościoła o naturze i misji kapłaństwa (T. Rincon-Perez, Święci szafarze, czyli duchowni w: Codex Iuris Canonici. Kodeks Prawa Kanonicznego. Komentarz. Powszechne i partykularne ustawodawstwo Kościoła katolickiego. Podstawowe akty polskiego prawa wyznaniowego, (red.) Piotr Majer, edycja polska na podstawie wydania hiszpańskiego, Kraków 2011, s. 223-274). Konferencja Episkopatu Polski uchwaliła „Ratio intitutionis sacerdotalis pro Polonia” i „Ratio studiorum”, zatwierdzone przez Kongregację Wychowania Katolickiego w 1999 r., (zob. Ratio institutionis sacerdotalis pro Polonia. Zasady formacji kapłańskiej w Polsce i Ratio studiorum. Program studiow $w$ wyższych seminariach duchownych $w$ Polsce opublikowano razem pod tytułem: Ratio institutionis sacerdotalis pro Polonia. Zasady formacji kapłańskiej w Polsce, Częstochowa 1999). 
historyczne, społecznokulturalne i kościelne, w których kapłan powołany jest do realizacji misji Chrystusa i Kościoła, co spowodowało również znaczące zmiany dotyczące innych aspektów: obrazu lub wizji kapłana, potrzeb duchowych Ludu Bożego, wyzwań nowej ewangelizacji, języka komunikacji itd. Dostrzegając te przeobrażenia Kongregacja ds. Duchowieństwa w dniu 8 grudnia 2016 r. ogłosiła nowy dokument regulujący sprawy związane $\mathrm{z}$ formacją przyszłych kapłanów. Aktualne „Ratio fundamentalis institutionis sacerdotalis” wykorzystuje treści, metody i wskazania dotyczące formacji już istniejące, uaktualniając je jednak oraz wprowadzając nowe elementy. W dokumencie znalazły się wskazania zaoferowane przez Adhortację apostolską „Pastores dabo vobis” z 1992 roku $^{9}$, dotyczące formacji integralnej, tj. zdolnej do połączenia w sposób wyważony wymiar ludzki z duchowym, intelektualnym i duszpasterskim, na drodze pedagogicznej stopniowej i dostosowanej do indywidualnych potrzeb kandydata.

Najnowsze „Ratio fundamentalis”, podobnie jak to z 1970 r., obejmuje również „Ordo studiorum”, zawierające wykaz dyscyplin naukowych, które powinny wchodzić w skład ogólnego programu studiów. Podkreśla, iż w „Ratio” krajowym, opracowanym przez Konferencje Episkopatów, powinien być zawarty wykaz przedmiotów przewidzianych $\mathrm{w}$ formacji intelektualnej na każdym etapie formacyjnym. Winny być też ukazane w sposób zwięzły cele każdego przedmiotu oraz kontekstualizacja danego przedmiotu w całości nauczania. Przedmioty, które „Ratio fundamentalis” przedstawia w ramach studiów propedeutycznych, filozoficznych i teologicznych, oraz te „służące bezpośrednio posłudze kapłańskiej”, tworzą strukturę zasadniczą studiów w seminariach oraz we wszystkich domach formacyjnych. Będą one mogły być uzupełnione przez Konferencje Episkopatów, mając na uwadze ich tradycję formacyjną i specyficzne potrzeby duszpasterskie.

\footnotetext{
${ }^{8}$ Dalej jako Ratio fundamentalis.

${ }^{9}$ Jan PAweŁ II, Adhortacja apostolska Pastore dabo vobis (25 marca 1992 r.), w: Jan Paweł II, Dzieła zebrane. Tom II - Adhortacje, Kraków 2006, 9-10.
} 
W odniesieniu do przedmiotu prawa kanonicznego „Ratio fundamentalis” w pkt. 174, nawiązując do słów użytych przy promulgacji Kodeksu Prawa Kanonicznego z 1983 r. stwierdza, iż „[...] całe prawo Kościoła może być pojmowane jako wielki pas transmisyjny przenoszący na język kanonistyczny [...] soborową eklezjologię. Choć nie da się obrazu Kościoła w ujęciu doktryny Soboru doskonale przełożyć na język kanonistyczny, to jednak Kodeks powinien się odnosić do tego obrazu jako pierwotnego wzoru, którego zarys powinien on odpowiednio, o ile to możliwe, z samej swej natury wyrażać10". Równocześnie zauważa się między innymi, iż w ramach właściwego rozeznania sytuacji kościelnych prawo kanoniczne wspiera skuteczną działalność duszpasterską. W obrębie duszpasterstwa rodzin wiele problemów i „ran” może znaleźć lekarstwo poprzez środki zaoferowane przez prawo kościelne, tak aby „stale sprzyjały dobru wiernych, zgodnie z darami i misją każdego z nich"11.

W przypadku „przedmiotów służących bezpośrednio posłudze kapłańskiej” w pkt. 176 analizowanego dokumentu zwraca się uwagę, iż znajomość tych przedmiotów jest wymagana przede wszystkim ze względu na specyficzne potrzeby przyszłej posługi duszpasterskiej, która ma być wykonywaną w konkretnym kontekście czasu i miejsca. Do takich przedmiotów „Ratio fundamentalis” zalicza między innymi zarząd dobrami, stwierdzając w pkt. 180, iż seminarzyści winni otrzymać staranną formację dotyczącą zarządu dobrami, aby czynić to zgodnie z wymogami prawa kanonicznego i z właściwą kompetencją. Formacja ta winna zawierać podstawowe elementy prawa cywilnego w tej materii, ze zwróceniem uwagi na szczególne obowiązki proboszcza.

Biorąc zatem pod uwagę wskazane założenia i wymogi dotyczące formacji w zakresie szeroko pojmowanego prawa kanonicznego, jak również biorąc pod uwagę to, że w pkt. 7 omawianego dokumentu

\footnotetext{
${ }^{10}$ JAN PAWEŁ II, Konstytucja apostolska Sacrae disciplinae leges (25 stycznia 1983), AAS 75 (1983), cz. II, s. XI.

${ }^{11}$ Papież Franciszek, List apostolski Motu proprio Mitis Iudex Dominus Iesus (15 sierpnia 2015 r.), Tarnów 2015.
} 
prawodawca kościelny wyraźnie podkreśla, że kandydaci do kapłaństwa winni być formowani tak, aby byli należycie przygotowani do „stawienia czoła wyzwaniom naszych czasów” z uwzględnieniem realiów własnego kraju, nie sposób nie zadać pytania, czy w nauczaniu prawa kanonicznego owe „wyzwania czasów” są dostrzegalne? Czy w ciągu wspomnianych 30 lat formacji kolejnych roczników kandydatów do kapłaństwa, nie pojawiły się takie problemy i zagadnienia dotyczące prawa kanonicznego, które wymagają nowego, naukowego spojrzenia i nowego, dydaktycznego ujęcia? Czy nie ma w nim żadnych anachronizmów, które nie przystają do realiów współczesności?

Wyczerpująca odpowiedź na powyższe pytania niewątpliwie wykraczałaby poza ramy zakreślone formą tej publikacji. Nie pretendując zatem do całościowego ujęcia tematu, analizie poddano jedynie wybrane zagadnienia w trzech kluczowych kontekstach: w kontekście jurydycznym, prawnomajątkowym oraz w kontekście prawnorodzinnym i społecznym, z uwzględnieniem specyfiki polskiego porządku prawnego.

\section{Kontekst jurydyczny}

Pierwsza wątpliwość jaka pojawia się niejako już w punkcie wyjścia dotyczy kwestii w pewnym sensie podstawowej a mianowicie tego, jaki status ma prawo kanoniczne w przestrzeni prawnopublicznej w Polsce?

Zgodnie z treścią art. 87 ust. 1 i 2 oraz art. 90 Konstytucji z 1997 r. prawo kanoniczne nie jest źródłem prawa powszechnie obowiązującego w Rzeczypospolitej Polskiej. Nie może być również uznane za umowę międzynarodową, ani za prawo stanowione przez organizację międzynarodową. Prawo kanoniczne nie jest też ogłaszane w żadnym polskim organie promulgacyjnym ani w organie promulgacyjnym organizacji międzynarodowej, której Polska jest członkiem. Niewątpliwie nie ma ono zatem mocy powszechnie obowiązującej na terytorium RP. Może ono wywoływać skutki prawne w porządku prawa polskiego tylko na podstawie zezwolenia wynikającego z przepisu ustawy i tylko w zakresie tym zezwoleniem objętym. Takie „zezwolenie" ustawowe występuje w odniesieniu do kwestii związanych 
z zawieraniem małżeństwa wyznaniowego ze skutkami cywilnymi. Czy jednak prawo kanoniczne jest traktowane jako „prawo” w innych aspektach polskiego prawa cywilnego np. w tych kwestiach, które dotyczą reprezentacji podmiotów kościelnych w obrocie cywilnoprawnym? Czy może jest ono - jak twierdzą niektórzy przedstawiciele cywilistyki polskiej - tylko zespołem norm o charakterze moralnym? A jeśli jest „prawem”, to czy stanowi ono „właściwe przepisy” w rozumieniu art. 35 k.c. ${ }^{12}$, czy też ma charakter jedynie „statutu”, o którym w tym przepisie mowa.

Według postanowienia Sądu Najwyższego z 18 kwietnia 1963 r. w sprawie ICR $223 / 63^{13}$ przepisy prawa kanonicznego przed utratą mocy obowiązującej Konkordatu z 10 lutego 1925 r. miały charakter wewnętrznego prawa statutowego. We współczesnej judykaturze oraz literaturze przedmiotu stanowiska w tej kwestii są podzielone. W wyroku z 24 marca 2004 r. Sąd Najwyższy stanął na stanowisku, iż prawo kanoniczne „[...] musi być traktowane i uwzględniane w świetle art. 35 k.c. i art. 38 k.c. na równi z wymienionymi w tych przepisach ustawami, a nie statutami", natomiast w uchwale z 19 grudnia 2008 r. Sąd ten wyraził pogląd o „podwójnej statutowości” norm prawa wewnętrznego. Według tego ostatniego poglądu, zarówno przepisy prawa kanonicznego jak i wydane na ich podstawie statuty kościelnych osób prawnych mają rangę statutów w znaczeniu wynikającym z art. 35 k.c. i 38 k.c. Nie wyklucza to - jak zauważa Sąd Najwyższy „dwupłaszczyznowości” tak rozumianej regulacji statutowych, tzn. normy ogólne prawa kanonicznego mają w takim układzie charakter norm nadrzędnych, zaś statuty - norm podrzędnych ${ }^{14}$.

Spór o to, czy normy prawa wewnętrznego Kościoła są w świetle regulacji państwowych jedynie zbiorem norm moralnych nie będących prawem, czy mają rangę statutów czy też są wreszcie prawem

\footnotetext{
${ }^{12}$ Ustawa z dnia 23 kwietnia 1964 r. Kodeks cywilny, Dz. U 1964, Nr 16, poz. 93 z późn. zmn.

${ }^{13}$ Postanowienie SN z dnia 18.04.1963, ICR 223/63, OSPiKA 1965, z. 1, poz. 6.

${ }^{14}$ M. ToмкIEwICz, Obrót majątkiem Kościoła Rzymskokatolickiego w Polsce, Olsztyn 2013, s. 208.
} 
właściwym, zdaje się mieć kontekst szerszy i dotykać generalnie problemu stosunku unormowań państwowych do prawa wewnętrznego związków wyznaniowych. Nie wchodząc w szczegóły istniejących w tym względzie ogólnych teorii dość powiedzieć, że wskazane wyżej poglądy negujące „prawny” charakter prawa kościelnego, bądź też przypisujące mu jedynie rangę statutu bądź też uznające je za prawo właściwe, zdają się nawiązywać do istniejącej w tym względzie „teorii pozaprawnej natury”, „teorii natury statutowej” i „teorii recepcji”15.

Rozpatrywanie prawa kanonicznego w kategoriach statutu wydaje się być niewłaściwe. Treść art. 35 k.c. i art. 38 k.c. nie pozostawia bowiem wątpliwości, że statut musi być aktem zakotwiczonym we „właściwych przepisach” i zgodnym z imperatywami w tych przepisach określonymi ${ }^{16}$. Jeśli prawo kanoniczne miałoby być jedynie statutem, to rodzi się pytanie, w jakim akcie wyższego rzędu miałoby znajdować ono swoją podstawę? Szukanie normatywnej podstawy prawa kanonicznego w porządku prawa państwowego z oczywistych względów naruszałoby porządek prawny Kościoła, który zakłada istnienie w tymże Kościele władzy prawodawczej otrzymanej od Boskiego Założyciela ${ }^{17}$, a ponadto godziłoby w konstytucyjną zasadę niezależności i autonomii Kościoła i państwa ${ }^{18}$.

Niewłaściwość traktowania prawa kanonicznego w kategoriach statutu wynika jednakże przede wszystkim z faktu, że sam ustawodawca polski, jakkolwiek nie wymienia prawa kanonicznego wśród źródeł prawa powszechnego, to jednakże traktuje prawo kanoniczne jako „prawo” a nie „statut”. Świadczą o tym jednoznacznie zapisy w szeregu aktów ustawodawczych: np. art. 2, art. 15 ust. 1 i 2 Ustawy z dnia 17 maja 1989 r. o stosunku Państwa do Kościoła Katolickiego

\footnotetext{
${ }^{15}$ Szerzej zob. H. Misztal, Wprowadzenie do prawa wyznaniowego, w: H. Misztal, P. Stanisz (red.), Prawo wyznaniowe, Lublin 2003, s. 32-33.

${ }^{16}$ M. Pyziak-Szafnicka (red.), Kodeks cywilny. Część ogólna. Komentarz, Warszawa 2009, s. 375.

17 T. Pawluk, Prawo kanoniczne według Kodeksu Jana Pawła II. Tom I. Zagadnienia wstępne i normy ogólne, Olsztyn 1985, s. 31.

${ }^{18}$ M. Toмkiewicz, Obrót majątkiem..., dz. cyt., s. 191-211.
} 
w Rzeczypospolitej Polskiej ${ }^{19}$ czy art. 4 ust. 2, art. 5, art. 8 ust. 2, art. 14, art. 16 Konkordatu ${ }^{20}$ z 1993 r. Po wtóre, odwołanie do prawa kanonicznego zamieszczone zostało w tak szczególnym i znaczącym akcie jak preambuła do Konkordatu między Stolicą Apostolską i Rzecząpospolitą Polską z dnia 28 lipca 1993 r. W sposób znamienny dowodzi to, że państwo polskie nie tylko „dostrzega” i „toleruje” prawo kanoniczne jako system prawny istniejący na terytorium Rzeczpospolitej Polskiej ale uznaje też jego wagę i znaczenie ${ }^{21}$. Jest to zrozumiałe zważywszy na wkład jakie prawo kanoniczne wniosło w ukształtowanie się zarówno podwalin prawa w Polsce (i Europie) ${ }^{22}$, jak i w ukonstytuowaniu niektórych istniejących do dziś rozwiązań prawa świeckiego ${ }^{23}$.

W kontekście powyższego w pełni zgodzić się należy z poglądem Sądu Najwyższego wyrażonym we wspomnianym uzasadnieniu wyroku z 24 marca 2004 r., iż w świetle art. 35 k.c. i art. 38 k.c. prawo kanoniczne w zakresie funkcjonalnym winno być traktowane i uwzględniane na równi z przepisami ustawy ${ }^{24}$. Taki sposób postrzegania prawa kanonicznego winien być prezentowany również - jak wydaje się - w toku formacji seminaryjnej w Polsce.

\section{Kontekst prawnomajątkowy}

Pytanie o status prawa kanonicznego w porządku prawa świeckiego w Polsce jest pytaniem aktualnym i ważnym nie tylko w kontekście debaty naukowej ale przede wszystkim dlatego, że ma ono

${ }^{19}$ Dz. U. 1989, Nr 29, poz. 154, z późn. zmn.

${ }^{20}$ Dz. U. 1998, nr 51, poz. 318.

${ }^{21}$ Tamże.

${ }^{22}$ Szerzej na ten temat: J. Danielou, H. I. Marrou, Historia Kościoła. Od początków do roku 600, t. 1, Warszawa 1986, s. 191 i nast.; M. D. KNowles, D. OBolensKi, Historia Kościoła, 600-1500, T. 2, Warszawa 1988, s. 115.

${ }^{23}$ Przykładem tego, że prawo kanoniczne wywierało bezpośredni wpływ na tworzenie się prawa polskiego jest m.in. fakt, iż to właśnie z prawa kanonicznego Sejm polski w 1594 r. przejął zasady dotyczące przedawnienia. Z prawa kanonicznego implementowano też zasadę zwrotu rzeczy odebranych gwałtem (M. ToMKIEwicz, Obrót majątkiem..., dz. cyt., s.208).

${ }^{24}$ Tamże. 
swoje praktyczne przełożenie m.in. dla całej sfery związanej z zarządem dobrami kościelnymi. To, czy proboszcz dokonując alienacji majątku parafialnego bez zgody biskupa i innych podmiotów, których zgoda jest wymagana w świetle prawa kanonicznego, dokonał czynności w pełni skutecznej czy też nieważnej w świetle prawa polskiego, jest zagadnieniem wciąż spornym zarówno dla praktyków, jak i teoretyków prawa ${ }^{25}$.

${ }^{25} \mathrm{Na}$ brak podstaw normatywnych recepcji prawa kanonicznego w zakresie
ograniczeń reprezentacji podmiotów kościelnych wskazują: M. PIETrzak, Prawo kanoniczne w polskim systemie prawnym, Państwo i Prawo 2006, nr 8, s. 16-30; G. RAdecki, Organy osób prawnych Kościoła Katolickiego w Polsce (na styku prawa kanonicznego i prawa cywilnego), Rejent 2003, nr 7-8, s. 144-155; tenże, Glosa do wyroku Sądu Najwyższego z dnia 27 lipca 2000 r. w sprawie IV CKN 88/00, OSP 2004, nr 5, poz. 58; tenże, Glosa do wyroku Sądu Najwyższego z dnia 24 marca 2004 r. w sprawie IV CK 108/03, Przegląd Sądowy 2006, nr 1, s. 134-140; M. JAsiAKIEwICZ, Glosa do wyroku Sądu Najwyższego z dnia 27 lipca 2000 r. w sprawie IV CKN 88/00, Rejent 2005, nr 1, s. 122-137; A. JANUCHOwsKi, Skuteczność prawa kanonicznego $w$ zakresie reprezentacji osób prawnych Kościoła katolickiego, Rejent 2007, nr 9, s. 49-67; tenże, Prawo kanoniczne a reprezentacja osób prawnych Kościoła katolickiego - problem przedstawicielstwa ustawowego i petnomocnictwa, Prawo Bankowe 2008, nr 1, s. 81; tenże, Glosa do uchwały Sądu Najwyższego z dnia 19 grudnia 2008 r. w sprawie III CZP 122/08, OSP 2010, nr 2, poz. 18, s. 127-132; J. Kuźmicka-Sulikowska, P. Machnikowski, Glosa do uchwały Sadu Najwyższego z dnia 19 grudnia 2008 r. w sprawie III CZP 122/08, OSP 2010, nr 2, poz. 18, s. 120-126; A. PAwluk, Glosa do uchwały Sądu Najwyższego z dnia 19 grudnia 2008 r. w sprawie III CZP 122/08, Rejent 2010, nr 7-8, s. 138-153; M. PLISIECKI, Glosa do uchwały Sądu Najwyższego z dnia 19 grudnia 2008 r. w sprawie III CZP 122/08, Rejent 2010, nr 7-8, s. 154-160. Na istnienie wspomnianych podstaw normatywnych wskazują: W. CHмiel, Obrót nieruchomościami przez parafię rzymskokatolicką, Rejent 2000, nr 6, s. 13-25; B. RA Koczy, Glosa do wyroku Sądu Najwyższego z dnia 27 lipca 2000 r. w sprawie IV CKN 88/00, OSP 2003, nr 9, poz. 115; tenże, Glosa do wyroku Sądu Najwyższego z dnia 24 marca 2004 r. w sprawie IV CK 108/03, Rejent 2005, nr 11, s. 131; tenże, Glosa do wyroku Sądu Najwyższego z 17 lutego 2005, IV CK 582/04, Gdańskie Studia Prawnicze - Przegląd orzecznictwa 2009, nr 2, s. 159-164; M. KRZEMIŃsKi, Znaczenie prawa kanonicznego dla określenia sposobu reprezentacji kościelnych osób prawnych. Glosa do wyroku SN z 27 lipca 2000r, IV CKN 88/00, Prawo Bankowe 2005, nr 10, s. 20-30; R. Szтүк, Kościoły i związki wyznaniowe jako podmioty czynności prawnych w praktyce notarialnej (cz. II), Rejent 2005, nr 2, 
Również Sąd Najwyższy, analizując przedmiotową materię co do tego, jakie skutki w porządku prawa cywilnego wywołuje dokonanie czynności prawnej dotyczącej obrotu majątkiem kościelnym z naruszeniem wymogów prawa kanonicznego, w orzeczeniach swoich dochodził do wniosków całkowicie ze sobą sprzecznych ${ }^{26}$. Odnotować jednakże należy, iż wprawdzie Sąd ten na przestrzeni lat kilkakrotnie

s. 82; tenże, Nabywanie i zbywanie nieruchomości przez kościelne osoby prawne, Rejent 2005, nr 6, s. 27-30); L. Świto, Alienacja majątku kościelnego w diecezjach rzymskokatolickich w Polsce, Olsztyn 2010, s. 185-194; M. Pietraszewski, Glosa do uchwały Sądu Najwyższego z dnia 19 grudnia 2008 r. w sprawie III CZP 122/08, Rejent 2010, nr 3, s. 211-230; M. Toмkiewicz, Obrót majątkiem Kościoła..., dz. cyt., s. 177-182. Zdaniem natomiast P. Stanisza brak unormowań dotyczących zakresu uprawnień organów kościelnych osób prawnych w przepisach prawa polskiego nie powinien być postrzegany jako odesłanie do prawa kanonicznego, ale raczej jako uznanie, że kompetencje tych organów nie są ograniczone. Za skuteczne na forum państwowego porządku prawnego należy uznawać tylko te przepisy prawa kanonicznego, które są konieczne do odtworzenia normy obowiązującej w prawie polskim. Ustawa o stosunku Państwa do Kościoła Katolickiego zawiera regulację, która wprost określa, że np. proboszcz jest organem parafii, w związku z czym trudno zrozumieć - jak uważa ten autor - z jakich względów unormowanie to miałoby być niekompletne i powinno zostać uzupełnione o przepisy prawa kanonicznego, zob. tenże, Proboszcz jako reprezentant parafii rzymskokatolickiej w stosunkach majątkowych, w: K. Krasowski, M. Materniak-Pawłowska, M. Stanulewicz (red.), Prawo państwowe a prawo wewnętrzne związków wyznaniowych. Pamiętnik VII Zjazdu Katedr i Wykładowców Prawa Wyznaniowego, Gnieznol1-12.X.2010, Poznań 2010, s. 191-200.

${ }^{26}$ Wyrok SN z dnia 12.03.1997r., II CKN 24/97,wyrok niepublikowany, LEX nr 80725; Wyrok SN z 27.07.2000, IV CKN 88/00, OSP 2003, nr 9, poz. 115; Wyrok SN z 24.03.2004, IV CK 108/03,OSNC 2005, nr 4, poz. 65; Wyrok SN z 2.02.2005, IV CK 480/04, wyrok niepublikowany, LEX nr 177273; Wyrok SN z 17.02.2005, IV CK 582/04 wyrok niepublikowany, LEX nr 176007; Uchwała SN z 19.12.2008r., III CZP 122/08, OSNC 2009, z. 7-8, poz. 115; Wyrok SN z dnia 12.01.2011r, I CSK 182/10, Biuletyn SN 2011, nr 3, s. 15. Szerzej na ten temat zob.: M. STRZA£A, Skuteczność norm prawa kanonicznego w zakresie reprezentacji kościelnych osób prawnych w orzecznictwie Sądu Najwyższego, w: K. Krasowski, M. Materniak-Pawłowska, M. Stanulewicz (red.), Prawo państwowe a prawo wewnętrzne związków wyznaniowych. Pamiętnik VII Zjazdu Katedr i Wykładowców Prawa Wyznaniowego. Gnieznol1-12.X.2010, Poznań 2010, s. 211-221. 
zmieniał swoje poglądy w analizowanej materii, to jednak wciąż konsekwentnie stoi na stanowisku, iż dokonując oceny ważności tego rodzaju czynności należy brać pod uwagę normy wynikające z prawa wewnętrznego Kościoła.

Problem dotyczący oceny skutków cywilnoprawnych braku zgody kompetentnych podmiotów na alienację mienia kościelnego nie jest jednakże problemem jedynym, który w tej materii występuje. Nie mniejsze wątpliwości istnieją wewnątrz samej regulacji prawnokanonicznej i wiążą się z odpowiedzią na pytanie, jak współcześnie należy rozumieć pojęcie „patrimonium stabile”, którego rodowód sięga jeszcze Kodeksu Pio-Benedyktyńskiego oraz kim jest dziś osoba „zainteresowana”, której zgoda jest warunkiem koniecznym aktu alienacyjnego ${ }^{27}$. Wątpliwości powyższe dodatkowo potęguje fakt, iż w odniesieniu do wymogu uzyskania zgody Stolicy Apostolskiej w przypadku alienacji przekraczającej określoną kwotę maksymalną prawodawca kościelny posługuje się różną terminologią w zależności od tego, czy rzecz dotyczy alienacji dokonywanej w trybie kan. $1292 \$ 2$ KPK, czy też w trybie kan. $638 \$ 3 \mathrm{KPK}$, który odnosi się do instytutów zakonnych. O ile każdy z wymienionych przepisów analogicznie uzależnia obowiązek zwrócenia się o zgodę do Stolicy Apostolskiej od kwoty alienacji, o tyle sposób jej ustalenia każdy z nich określa inaczej. Norma kan. $638 \$ 3$ KPK wiąże tę kwotę z wartością alienacji (agatur de negotio quod summam a Sancta Sede pro cuiusque regione definitam superet), natomiast kan. $1292 \$ 2$ KPK zwartością dóbr alienowanych (de rebus quarum valor summam maximam excedit). Różnica w użytych sformułowaniach może wydawać się niewielka w swej warstwie redakcyjnej, jednakże w wymiarze praktyczno-prawnym powoduje daleko idące konsekwencje ${ }^{28}$, przy

\footnotetext{
${ }^{27}$ Szerzej zob. L. Świto, M. Tomkiewicz, Alienacja mienia kościelnego w ujęciu prawno-materialnym i proceduralnym: pytani $i$ wątpliwości, (w druku).

${ }^{28} \mathrm{~W}$ przypadku sprzedaży, zamiany lub darowizny określonych dóbr, wartość transakcji z reguły będzie tożsama $\mathrm{z}$ wartością tych dóbr, jednakże w innych przypadkach, jak np. w sytuacji zaciągania kredytu i ustanawiania hipoteki, obie te wartości nie muszą być (i z reguły nie są) jednakowe.
} 
czym można mieć wątpliwości, czy owe różnice prawodawca wprowadził świadomie i celowo.

Podobne wątpliwości zachodzą w przypadku określenia aktów zarządu. O ile bowiem rozróżnienie wskazanych w kan. 1281 \$ 1 i 2 KPK „aktów zwyczajnego zarządzania” (actus ordinariae administrationis) od „aktów przekraczających granice i sposób zwyczajnego zarządzania" (actus qui finem et modum ordinariae administrationis excedunt) nie nastręcza jeszcze większych trudności interpretacyjnych, o tyle wskazanie, w jakim przypadku mamy do czynienia $\mathrm{z}$ wymienionymi w kan. 1277 KPK „aktami zarządu o większym znaczeniu” (actus maioris momenti) a kiedy $\mathrm{z}$ „aktami nadzwyczajnego zarządzania” (actus extraordinariae administrationis), łatwe już nie jest. O obu ostatnio wymienionych terminach można w zasadzie powiedzieć jedynie tyle, że odnoszą się do aktów zarządu sprawowanego przez biskupa diecezjalnego w odniesieniu do dóbr diecezjalnych. Określenie jednak zakresu znaczeniowego każdego z tych pojęć oraz ich praktyczne rozróżnienie wciąż pozostaje wyzwaniem tak dla nauki prawa, jak i zarządców dóbr kościelnych ${ }^{29}$.

Pozostając w nurcie rozważań dotyczących alienacji nie sposób wreszcie nie odnotować i tego, że obowiązujące reguły alienacyjne dotyczące donaria votiva wyraźnie zdezaktualizowały się i trącą już anachronizmem. W tym aspekcie przypomnieć należy, iż poza patrimonium stabile przedmiotem alienacji mogą być również rzeczy darowane Kościołowi na podstawie ślubu a także rzeczy kosztowne $\mathrm{z}$ racji artystycznych lub historycznych. Pomiędzy alienacją patrimonium stabile a alienacją rzeczy darowanych Kościołowi na podstawi ślubu oraz rzeczy kosztownych z racji artystycznych lub historycznych zachodzi ta zasadnicza różnica, że o ile w przypadku majątku stałego zgoda Stolicy Apostolskiej związana jest z kwotą alienacji, o tyle w przypadku rebus ex voto Ecclesiae donatis oraz rzeczy kosztownych z racji artystycznych lub historycznych, konieczność uzyskania owej zgody Stolicy Apostolskiej nie jest uzależniona od

\footnotetext{
${ }^{29}$ Szerzej zob. L. Świto, Akty zarządu dobrami kościelnymi, Prawo Kanoniczne 58 (2015) nr 3, s. 105-116.
} 
wartości materialnej tych rzeczy. Bez względu na to, jaką wartość majątkową przedstawiałyby wymienione przedmioty, ich alienacja zawsze wymaga zezwolenia Stolicy Apostolskiej. Zgoda ta będzie zatem konieczna zarówno wtedy, gdy alienowana rzecz należąca do wymienionej kategorii dóbr ma wartość przekraczającą summa maxima, jak i wówczas gdy przedstawia niewielką wartość materialną.

W odniesieniu do dóbr darowanych Kościołowi na podstawie ślubu (rebus ex voto Ecclesiae donatis) wyjaśnić należy, iż - wbrew literalnemu brzmieniu - pojęcie to nie obejmuje każdej rzeczy przekazanej Kościołowi w wyniku aktu darowizny czy też realizacji złożonego uprzednio przyrzeczenia publicznego. W kan. $638 \$ 3$ i kan. $1292 \$ 2$ KPK chodzi jedynie o „dary wotywne” czyli - jak orzekła Kongregacja Soboru 14 stycznia 1921 r. - o przedmioty złożone na ołtarzu lub na poświęconym obrazie, o ile nic innego nie wskazuje na przeciwną wolę darczyńcy ${ }^{30}$. Zważywszy na fakt, iż wspomniane pojęcie darów wotywnych ukształtowane zostało w czasach dość odległych i w znacząco odmiennych realiach gospodarczo-społecznych, można mieć pewną wątpliwość, czy dalsze utrzymywanie specjalnych wymogów alienacyjnych w odniesieniu do tej grupy dóbr jest celowe. W sytuacji bowiem gdy dary wotywne byłyby przedmiotami o znaczącej wartości artystycznej lub historycznej ich alienacja i tak podlegałaby ochronie, takiej, jaką prawodawca kościelny przewiduje dla tej kategorii dóbr. W przypadku natomiast, gdy darami wotywnymi są np. przedmioty użytku codziennego, nie przedstawiające większej wartości ani historycznej ani artystycznej (np. inwalidzkie kule, narzędzia pracy itd.) można mieć wątpliwość, czy alienacja tego rodzaju przedmiotów rzeczywiście winna wymagać zgody samej Stolicy Apostolskiej.

Wszystkie wskazane wyżej wątpliwości winny być sygnalizowane w procesie nauczania prawa kanonicznego tak, aby seminarzyści będąc już zarządcami majątku kościelnego, mieli świadomość ich istnienia i skutków.

${ }^{30}$ L. Świto, Alienacja majątku..., dz. cyt., s. 110-111. 


\section{Kontekst prawnorodzinny i społeczny}

Prawo kanoniczne nie jest zbiorem norm wypreparowanych z kontekstu społecznego. Nie jest ono zatem również i wolne od dylematów związanych z przeobrażeniami społecznymi, w tym z przeobrażeniami obyczajowymi dotyczącymi małżeństwa i rodziny. Nie wchodząc w całą złożoność tematu a zatrzymując się jedynie na problemie stanowiącym - jak wydaje się - najbardziej znamienny i spektakularny wyraz owych przemian tj. na problemie tzw. „zmiany płci” odnotować należy, iż jakkolwiek doktryna kanoniczna jest zgodna co do tego, że prawnym wyznacznikiem weryfikującym ludzką płciowość jest płeć zdeterminowana biologicznie, w związku z czym dokonanie „zmiany płci” osób transseksualnych w drodze operacji de facto nie jest możliwe ${ }^{31}$ (operacja nie powoduje zmiany ontologicznej płci) ${ }^{32}$, to jednakże w odniesieniu do przyczyn nieważności małżeństwa osób, które zawarły je po dokonanym zabiegu dostosowującym, jednolitości poglądów wśród kanonistów nie ma.

Według G. Erlebacha zawarcie małżeństwa po chirurgicznej „zmianie płci” powoduje radykalną postać nieważności, którą należałoby nazwać jako „inexistentia matrimonii”, bowiem wówczas dochodzi do zawarcia małżeństwa przez dwie osoby o tej samej płci biologicznej ${ }^{33}$. Zdaniem natomiast R. Sobańskiego, w takim przypadku mamy do czynienia nie tyle $\mathrm{z}$ małżeństwem nieważnym, co nieistniejącym (matrimonium non existens) i w takiej sytuacji należy przeprowadzić skrócony proces o nieważność małżeństwa, który

\footnotetext{
${ }^{31}$ Szerzej zob. G. DzIERżon, Niezdolność do zawarcia małżeństwa jako kategoria kanoniczna, Warszawa 2002, s. 159.

${ }^{32}$ U. Navarette, Transsexualismus et ordo canonicus, Periodica 1997, nr 86, S. 101-124.

${ }^{33}$ G. ERLebACH, Tożsamość seksualna a nieważność związku mał̇̇eńskiego według najnowszej jurysprudencji rotalnej (1983-1994). Zarys systematyczny, w: B.W. Zuber (red.) Tożsamość seksualna nupturientów a zdolność do zgody małżeńskiej. Materiały I Międzynarodowego Sympozjum Prawa Kanonicznego zorganizowanego przez Katedrę Prawa Kanonicznego Wydziału Teologicznego Uniwersytetu Opolskiego w Opolu, 16 X 1996, Opole 1998, s. 130.
} 
winien się kończyć wydaniem orzeczenia stwierdzającego, że małżeństwo nie zostało zawarte.

Według m.in. M.F. Pompeddy, J. Hubera, U. Navarette transseksualista typu mężczyzna-kobieta $(\mathrm{M} / \mathrm{K})$ po przebytej operacji, na skutek której uzyskał narządy odpowiadające jego wyobrażeniom, traci zdolność do współżycia małżeńskiego i tym samym staje się impotentem (kan. $1084 \$ 1$ KPK). Zdaniem jednakże C. J. Ritty, G. Erlebacha i G. Biera w przypadku transseksualizmu M/K, ze względu na wysoki poziom nauk medycznych problem impotencji fizycznej nie musi zaistnieć. Inaczej rzecz przedstawia się w przypadku transseksualisty K/M. Tu kanoniści w zasadzie są zgodni, iż sztucznie wytworzone męskie organy płciowe nie są zdolne do współżycia, w związku z czym osoba po takim zabiegu nie jest zdolna do skonsumowania małżeństwa w sensie kanonicznym, a tym bardziej do pełnego stosunku (copula perfecta) ${ }^{34}$. C.J. Ritty uważa natomiast, że po przebytej operacji dostosowującej przeszkoda impotencji nie zachodzi ani w przypadku transseksualistów typu M/K, ani typu K/M

W przypadku niezdolności do wyrażenia konsensusu małżeńskiego w literaturze kanonicznej podkreśla się, iż istniejące u osoby transseksualnej napięcia (pomiędzy płcią genetyczną, gonadalną, somatyczną a płcią psychiczną) powodują tego rodzaju głębokie zaburzenia, że nie jest ona w stanie przyjąć i przekazać istotnych praw i obowiązków małżeńskich, nie jest zdolna do stworzenia wraz z partnerem wspólnoty całego życia i zbudowania prawdziwie interpersonalnych stosunków ${ }^{35}$, o czym mowa w kan. 1095 n. 3 KPK. Według J. Hubera, w pojedynczym przypadku zastosowanie może znaleźć kan. 1095 n. 2 KPK, gdy napięcie istniejące pomiędzy psychiką

\footnotetext{
${ }^{34}$ M. Toмkiewicz, Małżeństwo a zmiana płci w prawie polskim i kanonicznym zagadnienia procesowe, w: J. Krzywkowska, R. Sztychmiler (red.), Procedury w sprawach małżeńskich i rodzinnych. Teoria i praktyka, Olsztyn 2016, s. 97-106.

${ }^{35}$ Tamże, s. 104; J. Huber, Transseksualizm i transwestytyzm a zgoda małżeńska, w: B. Zuber (red.), Tożsamość seksualna nupturientów..., dz. cyt., s. 40.
} 
a ciałem będzie na tyle intensywne, że osoba transseksualna nie będzie w stanie dokonać prawdziwego wyboru ${ }^{36}$.

Nadmienić należy, iż w polskim prawie cywilnym zagadnienie zmiany płci jest postrzegane całkowicie odmiennie. Aktualnie dominuje pogląd, iż wprawdzie nie każda transpozycja płciowa może uzasadniać prawo do zmiany płci, zaś wybór i samookreślenie płci jest niedopuszczalne, o tyle zmiana płci osoby transseksualnej jest prawnie dozwolona a wydanie wyroku ustalającego płeć na podstawie art. 189 k.p.c. ${ }^{37}$ powoduje, że osoba transseksualna przynależy do płci ustalonej wyrokiem od dnia jego uprawomocnienia się. Osoba transseksualna, która uzyskała orzeczenie stwierdzające jej przynależność do danej płci, może zatem zawrzeć związek małżeński z osobą, która $\mathrm{w}$ odniesieniu do aktualnego zapisu zawartego w jej akcie urodzenia, jest płci przeciwnej, przy czym taka możliwość istnieje bez względu na to, czy osoba, której płeć ustalono w trybie art. 189 k.p.c poddała się zabiegowi chirurgicznej zmiany płci, czy też nadal posiada cechy fenotypowe swej płci „dotychczasowej”. W literaturze cywilistycznej podkreśla się również, iż zmiana płci co do zasady nie należy także do określonych w art. 10-16 k.r.o. przeszkód małżeńskich ${ }^{38}$, które mogłyby stanowić podstawę unieważnienia małżeństwa ${ }^{39}$.

\section{Zakończenie}

Udzielając odpowiedzi na pytania postawione we Wstępie stwierdzić należałoby, iż zaprezentowane powyżej wątpliwości przede wszystkim sygnalizują problemy (niektóre!), jakie napotyka prawo kanonicznego „w działaniu”, we współczesnych realiach społeczno-prawnych istniejących w Rzeczpospolitej Polskiej, a więc te problemy, z którymi przyjdzie się zmierzyć seminarzystom, gdy „pójdą

\footnotetext{
${ }^{36}$ J. Huber, Transeksualizm..., dz. cyt., s.40-41.

${ }^{37}$ Ustawa z dnia 17 listopada 1964 r. Kodeks postępowania cywilnego, Dz. U z 1964, Nr 43, poz. 296 z późn. zmn.

${ }^{38}$ Ustawa z dnia 25 lutego 1964 r. Kodeks rodzinny i opiekuńczy, Dz. U. 1964, Nr 9, poz. 59 z późn. zmn.

${ }^{39}$ M. Toмкiewicz, Małżeństwo a zmiana płci.., dz. cyt., s. 99.
} 
do Ludu Bożego", pełnić swą posługę kapłańską. Problemy te zdają się wskazywać, iż w aktualnym procesie formowania alumnów prawo kanoniczne winno być wykładane z większym uwzględnieniem regulacji prawa świeckiego obowiązujących na danym terytorium, co wydaje się być szczególnie pożądane zwłaszcza w przypadku prawa cywilnego i rodzinnego.

Przytoczone problemy zdają się również wskazywać na pewien anachronizm w zakresie uregulowań dotyczących, ogólnie rzecz ujmując, obrotu majątkiem kościelnym, przy czym anachronizm ten zauważalny jest zarówno w warstwie językowej, jak i w rozwiązaniach normatywnych, które nie tylko nie przystają do realiów współczesności ale przede wszystkim nie dają należytej ochrony dobrom kościelnym.

W tym miejscu wyraźnie zaznaczyć należy, iż zadaniem prawa kanonicznego niewątpliwie nie jest i nie może być kształcenie sprawnych menagerów, finansistów czy doradców prawnych. Formowanie do kapłaństwa winno jednakże formować ludzi świadomych, potrafiących odnajdować się w przestrzeni społecznej i umiejących obejmować duszpasterską troską zarówno powierzonych sobie ludzi jak i mienie kościelne, które jest wszak środkiem służącym realizacji misji zbawczej Kościoła. Nie ulega też wątpliwości, iż znajomość rozwiązań zarówno kanonicznoprawnych jak i cywilnoprawnych dotyczących małżeństwa i rodziny, zwiększa szanse skutecznej duszpasterskiej pomocy osobom borykającym się z różnymi kryzysami, $\mathrm{w}$ tym osobom dotkniętym dramatem zaburzeń związanych z identyfikacją płciową.

\section{Canon Law w in priestly formation. 'Formative tradition' and modern challenges in the light of Ratio fundamentalis institutionis sacerdotalis of 6 december 2016}

On 8 December 2016, in the document entitled Ratio fundamentalis institutionis sacerdotalis, the Confederation for the Clergy updated the general norms relating to priestly formation, applicable to the whole Church. Adoption of the new norms requires the Episcopal Conferences to establish a new national programme of priestly formation. The programme should, 
among others, redefine the curriculum of the seminaries, considering the circumstances and the needs identified in a given country.

This paper analyses the social and legal realities in the present-day Republic of Poland, indicating the most urgent problems to be considered while educating canon law alumni. Furthermore, it posits that canon law should be taught with stronger emphasis on the secular legal regulations applicable in Poland, particularly civil law and family law. The analysis also reveals a certain anachronism in the regulations governing dealings with church property.

SŁOWA KLUCzowE: formacja kapłańska; kształcenie kapłanów; prawo kanoniczne; duchowieństwo; ratio fundamentalis; seminarium duchowne

KEY WORDS: priestly formation; education of priests; canon law; clergy; ratio fundamentalis; theological seminary

\section{Nota o Autorze:}

Ks. DR hab. LuCjan Świto, PRof. UWM - kierownik Katedry Prawa Kanonicznego i Filozofii na Wydziale Teologii Uniwersytetu Warmińsko-Mazurskiego w Olsztynie, oficjał Metropolitalnego Sądu Archidiecezji Warmińskiej, konsultor Rady Prawnej Konferencji Episkopatu Polski. 